\title{
The Research on Trade Credit Short-term Financing in a Capital-constrained Supply Chain
}

\author{
Yang WANG ${ }^{1, a}$, Yue-Hong SHAO ${ }^{1, b}$, Jia-Quan $O U^{2, c}$ \\ ${ }^{1}$ School of Business Administration, South China University of Technology, China \\ ${ }^{2}$ School of Chemistry and Chemical engineering, South China University of Technology, China \\ abmywang@scut.edu.cn , bshao.yuehong@gmail.com, cou.jq@foxmail.com
}

Keywords: Supply chain finance, Capital constraint, Trade credit contract.

\begin{abstract}
In this paper we consider a supply chain consists of a single supplier and a single retailer which has the optimal order quantity. The supplier can offer the retailer short-term financing with a trade credit contract. The retailer has three payment choices: Full Payment; Full Credit; Partly Payment. We study a retailer which is capital constrained how to choose his payment scheme in order to optimize his efficiency. We conclude that the supplier is always willing to finance the retailer at rates no more than the risk-free rate. Furthermore, both profits of supplier and retailer improve with optimal trade credit contracts, and the supply chain efficiency always keeps the same.
\end{abstract}

\section{Introduction}

Capital, as the important resource that keeps a company's operations and development, usually makes a great influence on the development of the supply chain. Sometimes, a lack of capital will constrain production and purchase decisions made by a company. Manufacturers (or retailers) is hard to implement optimal production (or order) based on market demand because of capital-constraint. It is possible to cause a lack of production supply and price fluctuation, which may be harmful to the supply chain efficiency. However, the overall efficiency will be strengthened if a capital-constrained company gets financing service so the new value will be created in the supply chain. Therefore, financing service plays an important role in the modern management of supply chain. Commercial bank is one of sources that a company can get short-term financing, but SMEs and startups are difficult to get working capital that they need from commercial banks. It limits their development, even gets them into trouble. Therefore, solving the capital-constraint of enterprises in the supply chain is very important and urgent.

In recent years, many scholars have studied financing management in the capital-constrained supply chain. Buzacott and Zhang(2004) have research on integration of logistic and cash-flow. They build a strategy between a bank and a retailer under uncertain demand combining financing decision based on assets and production inventory decision [1]. For operations of supply chain facing a lack of capital, Raghavan and Mishra(2011) analyze the bank loan decision when retailer and supplier both face capital constraint in the supply chain. They consider that a bank who finances a manufacturer has a motivation to finance a retailer as well. They compare joint decision will be better than independent decision [2]. Margarita and Seifert make the optimal order decision of enterprises in the condition of capital restriction and delay payment by developing mathematical model. They analyze the effect of financial and operational decisions to supply chain performance [3]. In condition that supplier and retailer both face capital constraint, they will find trade credit will be more effective than real contract when they apply for financing from financial institutions (Lee \& Rhee,2010) [4]. Ouveils and Zhao (2012) find that profits of supplier and retailer and supply chain will be optimized if a supplier will provide an optimal trade credit contract to a retailer. Financing from a supplier will be better than a bank for a retailer [5].YongWu Zhou (2011) considers an inventory model with trade credit that consists of two parts. Assume that retailer pays a part of loan that can be allowed to pay delay with discount during a short period and will pay the remaining loan during next short period. Order strategy and payment plan will be made by developing models [6]. The supplier can offer two types of trade credit contracts to the retailer: 
one-part or two-parts. The research shows that two-parts contract is optimal to the supplier (Yuanguang Zhou\&Yongwu Zhou,2012) [7]. Lee and Rhee study trade-credit from a supplier's perspective, and consider trade-credit as a coordination tool of the supply chain. They make order decision of a retailer using newsvendor model and find the retailer should take trade credit financing or finance from banks to get the maximum profit [8].

At present, for the capital-constrained supply chain system that consists of retailers and suppliers, retailers have three financing methods: No financing service, financing service provided by financial institutions and trade credit financing service provided by core enterprises. Optimal order decisions will be made with different financing modes for retailers of different capital level (YongWu Zhou, YuanGuang Zhou,2011) [9]. Optimal decision models on retailers, manufacturers and banks and effect on optimal strategy of supply chain financing with different credit will be given, considering optimal strategy of supply chain financing in the warehouse receipt pledge financing mode based on credit (NiNa Yan, BaoWen Sun,2011) [10]. YiXue Li and GengZhong Feng study strategy on pledge rate and loan limit of commercial banks when they provide financing services to capital-constrained enterprises. They study financial and operation decision and find financing services will be able to create new value for a capital-constrained retailer [11]. They also study the different roles of third-party logistics enterprises in the operations of a capital-constrained supply chain, and make different decisions on financing and operations of relative enterprises.(XiangFeng Chen,2008) [12]. YuanYuan Zhang and JianBin LI (2008) discuss the inventory decision of enterprises with warehouse receipt pledge financing, and analyze the effect of pledge rate decided by banks to enterprises. Research shows that enterprises will not apply for loan only when they do not have enough fund if the loan value is low. Otherwise, enterprises will keep their own fund and order more with loan [13]. Yang Wang and YunLu Ma discuss with two financing methods led by suppliers: Supply chain financing service and Bank financing services. By analyzing financing profit model and comparing the advantage and disadvantage on the supply chain efficiency with centralized decision and decentralized decision, the result shows that Supply chain financing is better [14].

With closer relationship between enterprises, supply chain coordination is more and more important. Effective coordination mechanism of supply chain will help to optimize the supply chain efficiency. Ben Yong Hu et al. study the supply chain option flexibility contract with consideration of shortage of capital and analyze order strategy of the retailer and optimal production strategy of the supplier. They also give specific conditions to achieve the supply chain coordination, by adjusting wholesale price and option variables [15]. In the system that consists of a supplier and a retailer, Pareto improvement can be achieved using a trade credit contract (Tao Liu,2010) [16]. Meantime, some researchers raise credit incentive mechanism (QinHong Zhang, JianWen Luo,2009) [17] and discounted model of order quantity(Zonghong Cao, Yongwu Zhou,2011) [18] for coordination to maximize profit of the supply chain.

This paper will focus on the establishment of financing modes of the retailer and trade credit contracts which offered by the supplier in the capital-constrained supply chain system that is composed of a supplier and a retailer with optimal order quantity. The conclusion shows that trade credit contract can improve supply chain efficiency.

\section{Variables and Model}

According to Introduction, most of commercial banks are not willing to offer financing service to SMEs and startups in order to avoid risks because of their lack of pledged assets, lack of credit history and unsound guarantee mechanism. Actually, in the operations of modern enterprises, rich vendors will offer trade credit contracts to retailers which are capital-constrained in order to form value-added chain and broaden its marketing capability.

In this paper we consider a supply chain in a sales season which consists of a supplier and a retailer. A capital-constrained retailer needs to order products and strive for a financing contract from a supplier to satisfy uncertain demand. At first, the retailer will ask for a trade credit $\operatorname{contract}\left(w, r_{s}\right), w$ is discounted wholesale price and $r_{s}$ is interest rate that supplier allows delay 
payment of retailer. The retailer can choose whether to take the contract. Whether the retailer accepts contract offered by supplier depends on the setting of $r_{s}$.

When the sales season starts $(\mathrm{t}=0)$, the retailer finds his capital is not enough before he decides the order quantity of products. If the retailer chooses to ask the supplier for financing, the retailer can pay the supplier nothing or a part of payment depending on the values of $r_{s}$ and risk-free rate. Let $\alpha$ be the prepayment rate. The retailer will invest his rest of capital to earn the risk-free interest if any. The supplier produces and delivers products to the retailer after receiving order request. When the sales season ends $(t=T>0)$, the retailer need to pay the remainder of his order to the supplier at the price $w\left(1+r_{s}\right)$. If the sales revenue is not enough to pay for remaining loan, the retailer will be bankrupt and his remaining assets will be transferred to the supplier.

The decision variables of supplier are $\mathrm{w}$ andr $\mathrm{r}_{\mathrm{s}} \cdot \mathrm{r}_{\mathrm{s}}$ is the interest rate of supplier financing, and the risk-free interest rate $r_{f} \geq 0$. Assume that order quantity is $q$, the retailer's own fund is $B$, and his collateral assets pledged for short-term financing are $A$, then the retailer's wealth valued at the end of the sales season is $\Omega=\mathrm{A}+\mathrm{B}\left(1+\mathrm{r}_{\mathrm{f}}\right)$, and $\Omega>0$.If the retailer is bankrupt, he will pay his collateral assets for the debt. $P$ is unit retail price, $c$ is unit production cost. If $w\left(1+r_{f}\right)>p$, the retailer will not order. If $\mathrm{w}<c$, the supplier will not offer early payment discount. Therefore, we assumep $\geq \mathrm{w}\left(1+\mathrm{r}_{\mathrm{f}}\right) \geq \mathrm{c}\left(1+\mathrm{r}_{\mathrm{f}}\right)>0$. $\mathrm{k}$ is the minimum demand for the retailer to pay the loan. And the supplier's own fund is $\mathrm{M}$, his remaining fund will be invested to earn the risk-free interest. $\Pi_{r}, \Pi_{s}$ are the expected profits of retailer and supplier respectively, $\Pi$ is the supply chain profit. Salvage value and goodwill loss will not be discussed.

The uncertain demand $\mathrm{D}$ is a random variable, here $\mathrm{D} \in[0,+\infty]$, its probability density function is $f(D)$, cumulative distribution function is $F(D), F(D)$ is continuous , differentiable, increasing, and $\mathrm{F}(0)=0, \bar{F}(\mathrm{D})=1-\mathrm{F}(\mathrm{D})$.

$\mathrm{q}$ is the retailer's order quantity, $\mathrm{q}_{\mathrm{s}}\left(\mathrm{w}, \mathrm{r}_{\mathrm{s}}\right)$ is optimal order quantity in the condition of the given $\operatorname{contract}\left(\mathrm{w}, \mathrm{r}_{\mathrm{s}}\right)$, and the optimal contract is $\left(\mathrm{w}^{*}, \mathrm{r}_{\mathrm{s}}^{*}\right)$.

Other assumptions are the following:

(1) Both supplier and retailer are risk-neutral.

(2) Information is symmetrical between supplier and retailer.

(3) Both supplier and retailer are credit-worthy.

(4) Do not consider the lack of production.

(5) Do not consider the lead-time of order.

\section{Decision Model}

As previously mentioned, with the trade credit contracts which the supplier offers, the retailer can pay totally in advance if his capital is enough. If not, the retailer can choose to pay nothing or a part of payment based on the trade credit contracts and limit of capital to get financing from the supplier.

According to the prepayment rate $\alpha$, the retailer has three financing choices: Scheme 1(Full Payment, $\alpha=1$ ); Scheme 2(Full Credit, $\alpha=0$ ); Scheme 3(Partly Payment, $0<\alpha<1$ ). The expected profits of supplier and retailer and the supply chain efficiency will be discussed as below.

Let $(\mathrm{a})^{+}=\max \{\mathrm{a}, 0\}$, At $\mathrm{t}=0$, the retailer asks the supplier for financing $(\mathrm{wq}-\mathrm{B})^{+}$with the rate $r_{s}$, orders products and pays the supplier $w q$ in advance, then invest the rest $(B-w q)^{+}$ to earn the risk-free interest. When the sales season ends, the retailer will pay his remaining payment using his assets including the sales revenue, $p \cdot \min (D, q)$, investment return, $(B-$ $\mathrm{wq})^{+}\left(1+\mathrm{r}_{\mathrm{f}}\right)$ and collateral assets $\mathrm{A}$, then retailer's expected profit is :

$$
\Pi_{r}\left(q, w, r_{s}\right)=E\left[p \cdot \min (D, q)+A+(B-w q)^{+}\left(1+r_{f}\right)-(w q-B)^{+}\left(1+r_{s}\right)\right]^{+}
$$

Let $\mathrm{k}(\mathrm{q}, \mathrm{w}, \mathrm{r})$ be the minimum demand for the retailer to pay the loan, then,

$$
\mathrm{k}\left(\mathrm{q}, \mathrm{w}, \mathrm{r}_{\mathrm{s}}\right)=\frac{\left[(\mathrm{wq}-\mathrm{B})^{+}\left(1+\mathrm{r}_{\mathrm{s}}\right)-\mathrm{A}-(\mathrm{B}-\mathrm{wq})^{+}\left(1+\mathrm{r}_{\mathrm{f}}\right)\right]^{+}}{\mathrm{p}}
$$


$\mathrm{k}\left(\mathrm{q}, \mathrm{w}, \mathrm{r}_{\mathrm{s}}\right)=0$ if $\mathrm{B} \geq \mathrm{wq} . \mathrm{w}\left(1+\mathrm{r}_{\mathrm{s}}\right) \geq \mathrm{p}$ if $k\left(\mathrm{q}, \mathrm{w}, \mathrm{r}_{\mathrm{s}}\right) \geq q$. Then the retailer will not accpet this trade credit contract.Therefore, when $k\left(\mathrm{q}, \mathrm{w}, \mathrm{r}_{\mathrm{s}}\right)<q$, we have

$$
\begin{aligned}
& \Pi_{r}\left(q, w, r_{s}\right)=p E\left[\min (D, q)-\min \left(D, k\left(q, w, r_{s}\right)\right)\right]^{+}+\left[A+(B-w q)^{+}\left(1+r_{f}\right)-(w q-\right. \\
& \left.B)^{+}\left(1+r_{s}\right)\right]^{+}
\end{aligned}
$$

When the order quantity meets the condition that marginal profit is equal to marginal cost, the retailer will gain the maximum profit. That is the optimal order quantity for the retailer.

If $p \cdot \min (D, q)+A+(B-w q)^{+}\left(1+r_{f}\right) \geq(w q-B)^{+}\left(1+r_{s}\right)$, the supplier will obtain the total loan $(w q-B)^{+}\left(1+r_{s}\right)$. Otherwise, the retailer will be bankrupt, and the supplier can only receive $p \cdot \min (D, q)+A+(B-w q)^{+}\left(1+r_{f}\right)$. Assume that the supplier has his own fund $M$, and invests the rest $\mathrm{M}-\mathrm{cq}_{\mathrm{s}}$ after spending for production, then the investment return is $\left(\mathrm{M}-\mathrm{cq}_{\mathrm{s}}\right)\left(1+\mathrm{r}_{\mathrm{f}}\right)$ at the end of the sales season.

Assume N(D) is the total amount of repayment that the supplier receives from the retailer. Therefore, at the end of the sales season $(t=T)$, the supplier's expected profit is :

$$
\Pi_{s}\left(q, w, r_{s}\right)=E[N(D)]-c q\left(1+r_{f}\right)+M\left(1+r_{f}\right)
$$

and,

$$
\begin{aligned}
E[N(D)]=E[ & \left.\min \left\{p \cdot \min (D, q)+A+(B-w q)^{+}\left(1+r_{f}\right),(w q-B)^{+}\left(1+r_{s}\right)\right\}\right] \\
& =E[p \cdot \min (D, q)]+A+(B-w q)^{+}\left(1+r_{f}\right) \\
& -E\left[p \cdot \min (D, q)+A+(B-w q)^{+}\left(1+r_{f}\right)-(w q-B)^{+}\left(1+r_{s}\right)\right]^{+} \\
& =E[p \cdot \min (D, q)]+A+(B-w q)^{+}\left(1+r_{f}\right)-\Pi_{r}(q, w, r)
\end{aligned}
$$

We can find from Eq.4 that the supplier's own fund M will make no difference on decision of optimal trade credit contract, so it can be ignored.

Full Payment, the prepayment rate $\alpha=1$

If the retailer has enough working capital $(\mathrm{wq} \leq B)$, and his order can be prepaid, then the retailer's expected profit is

$$
\Pi_{r}^{1}\left(q, w, r_{s}\right)=p E[\min (D, q)]+A+(B-w q)\left(1+r_{f}\right)
$$

The optimal order quantity of the retailer is

$$
\mathrm{q}_{\mathrm{s}}^{1}\left(\mathrm{w}, \mathrm{r}_{\mathrm{s}}\right)= \begin{cases}\bar{F}^{-1}\left(\mathrm{w}\left(1+\mathrm{r}_{\mathrm{f}}\right) / \mathrm{p}\right) & \mathrm{wq}<B \\ \frac{\mathrm{B}}{\mathrm{w}} & \mathrm{wq}=\mathrm{B}\end{cases}
$$

The supplier's expected profit is

$$
\Pi_{s}^{1}\left(q, w, r_{s}\right)=(w-c) q\left(1+r_{f}\right)
$$

The supply chain efficiency is

$$
\Pi_{1}=\Pi_{\mathrm{r}}^{1}+\Pi_{\mathrm{s}}^{1}=\mathrm{pE}[\min (\mathrm{D}, \mathrm{q})]+\mathrm{A}+(\mathrm{B}-\mathrm{cq})\left(1+\mathrm{r}_{\mathrm{f}}\right)
$$

When the retailer is capital-constrained, he cannot meet downstream marketing demand so he 
cannot expand operations, and the supply chain efficiency cannot achieve optimization. Therefore, methods including financing and loan should be considered to achieve the maximum profits of each other and the supply chain when the retailer has not enough capital(wq $>B)$.

\section{Full Credit, the prepayment rate $\alpha=0$}

At $\mathrm{t}=0$, the retailer orders products $\mathrm{q}$ from the supplier, but pays nothing, and invests his working capital to earn the risk-free interest. At the end of the sales season, the retailer will pay remaining order $w q\left(1+r_{s}\right)$ to the supplier. If $p \cdot \min (D, q)+A+B\left(1+r_{f}\right) \geq w q\left(1+r_{s}\right)$, the supplier can get full payment $w q\left(1+r_{s}\right)$ from the retailer. Otherwise, the retailer will be bankrupt, and the supplier can only receive $p \cdot \min (D, q)+A+B\left(1+r_{f}\right)$.

As the supplier is risk-neutral, his expected profit towards different projects should be the same. So financing that the supplier offers to the retailer should satisfy the condition that the expected profit is equal to average profit of capital market investment. So

$$
\int_{0}^{k} p \cdot D \cdot f(D) d D+\int_{k}^{\infty} p \cdot k \cdot f(D) d D=w q\left(1+r_{f}\right)
$$

and,

$$
\mathrm{k}=\left[\mathrm{wq}\left(1+\mathrm{r}_{\mathrm{s}}\right)-\mathrm{A}-\mathrm{B}\left(1+\mathrm{r}_{\mathrm{f}}\right)\right] / \mathrm{p}
$$

The retailer's expected profit is

$$
\Pi_{r}^{2}\left(q, w, r_{s}\right)=p E[\min (D, q)]+A+B\left(1+r_{f}\right)-w q\left(1+r_{s}\right)
$$

The optimal order quantity of the retailer is

$$
\mathrm{q}_{\mathrm{s}}^{2}\left(\mathrm{w}, \mathrm{r}_{\mathrm{s}}\right)=\bar{F}^{-1}\left(\mathrm{w}\left(1+\mathrm{r}_{\mathrm{s}}\right) / \mathrm{p}\right)
$$

The supplier's expected profit is

$$
\Pi_{s}^{2}\left(q, w, r_{s}\right)=\text { we } q\left(1+r_{s}\right)-c q\left(1+r_{f}\right)
$$

The supply chain efficiency is

$$
\begin{aligned}
& \Pi_{2}=\Pi_{r}^{2}+\Pi_{s}^{2}=p E[\min (D, q)]+A+B\left(1+r_{f}\right)-w q\left(1+r_{s}\right)+w q\left(1+r_{s}\right)-c q\left(1+r_{f}\right)= \\
& p E[\min (D, q)]+A+(B-c q)\left(1+r_{f}\right)
\end{aligned}
$$

\section{Partly Payment, the prepayment rate $0<\alpha<1$}

At $\mathrm{t}=0$, the retailer's own fund is $\mathrm{B}$. The capital-constrained retailer orders products $\mathrm{q}$ from the supplier and pay a part of amount to the supplier. The prepayment rate is $\alpha=\frac{\mathrm{B}}{\mathrm{wq}}$. The remaining order valued $(q-B / w)$ will be financed from the supplier. That is to say, the retailer will pay remaining loan $w\left(1+r_{s}\right)(q-B / w)$ to the supplier at the end of the sales season. That means the supplier offers financing service $(w q-B)\left(1+r_{s}\right)$ to the retailer. The retailer will gain sales revenue $p \cdot \min (D, q)$ when sales season ends. If $p \cdot \min (D, q)+A \geq(w q-B)(1+r)$, the supplier will gain the remaining loan $(w q-B)\left(1+r_{s}\right)$. Otherwise, the retailer will be bankrupt, and the supplier can only get $\mathrm{p} \cdot \min (\mathrm{D}, \mathrm{q})+\mathrm{A}$ back.

Because expected profit is equal to average profit of capital market investment, we can obtain 
$\int_{0}^{k} p \cdot D \cdot f(D) d D+\int_{k}^{\infty} p \cdot k \cdot f(D) d D=(w q-B)\left(1+r_{f}\right)$

and,

$$
\mathrm{k}=\left[(w q-B)\left(1+r_{s}\right)-A\right] / p
$$

Simplify Eq.13,

$$
\mathrm{k} \bar{F}(\mathrm{k})=\mathrm{k}\left(1+\mathrm{r}_{\mathrm{f}}\right) /\left(1+\mathrm{r}_{\mathrm{s}}\right)-\int_{0}^{\mathrm{k}} \mathrm{D} \cdot \mathrm{f}(\mathrm{D}) \mathrm{dD}
$$

$\mathrm{k}$ is the minimum demand for the retailer to pay the loan. If demand is larger than $\mathrm{k}$, the supplier will get the expected profit from financing. Otherwise, the supplier will bear the loss and cannot get the remaining loan back. From Eq.5 we know, the interest rate of supplier financing $r_{s}$ is related to the retailer's order quantity $q$, the retailer's own fund $B$ and the risk-free rate $r_{f}$.

Proposition 1. As an risk-neutral investor, the interest rate of supplier financing $r_{s}$ will increase as the retailer's order quantity $q$ and the risk-free rate $r_{f}$ increase and it will decrease as the retailer's own fund $\mathrm{B}$ increases.

Let

$$
\begin{aligned}
& U\left(q, B, r_{f}, r_{s}\right) \\
& =\int_{0}^{(w q-B)\left(1+r_{s}\right) / p} p \cdot D \cdot f(D) d D+\int_{(w q-B)\left(1+r_{s}\right) / p}^{\infty}(w q-B)\left(1+r_{s}\right) \cdot f(D) d D \\
& -(w q-B)\left(1+r_{f}\right)
\end{aligned}
$$

Take its partial respect to $r_{s}, q, B, r_{f}$, we can obtain,

$$
\begin{aligned}
& \frac{\partial U}{\partial r_{s}}=\int_{(w q-B)\left(1+r_{s}\right) / p}^{\infty}(w q-B) \cdot f(D) d D ; \\
& \frac{\partial U}{\partial q}=\int_{(w q-B)\left(1+r_{s}\right) / p}^{\infty} w\left(1+r_{s}\right) \cdot f(D) d D-w\left(1+r_{f}\right) ; \\
& \frac{\partial U}{\partial B}=-\int_{(w q-B)\left(1+r_{s}\right) / p}^{\infty}\left(1+r_{s}\right) \cdot f(D) d D+\left(1+r_{f}\right) ; \\
& \frac{\partial U}{\partial r_{f}}=B-w q .
\end{aligned}
$$

$r_{s}$ takes its partial respect to $q, B, r_{f}$, we can obtain,

$$
\begin{aligned}
& \frac{\mathrm{dr}_{\mathrm{s}}}{\mathrm{dq}}=-\frac{\partial \mathrm{U}}{\partial \mathrm{q}} / \frac{\partial \mathrm{U}}{\partial \mathrm{r}_{\mathrm{s}}}=\frac{\mathrm{w}\left[\left(1+\mathrm{r}_{\mathrm{f}}\right)-\left(1+\mathrm{r}_{\mathrm{s}}\right) \cdot \bar{F}_{\left.\left((\mathrm{wq}-\mathrm{B})\left(1+\mathrm{r}_{\mathrm{s}}\right) / \mathrm{p}\right)\right]}\right.}{(\mathrm{wq}-\mathrm{B}) \cdot \bar{F}_{\left((\mathrm{wq}-\mathrm{B})\left(1+\mathrm{r}_{\mathrm{s}}\right) / \mathrm{p}\right)}} \\
& \frac{\mathrm{dr}_{\mathrm{s}}}{\mathrm{dB}}=-\frac{\partial \mathrm{U}}{\partial \mathrm{B}} / \frac{\partial \mathrm{U}}{\partial \mathrm{r}_{\mathrm{s}}}=\frac{\left(1+\mathrm{r}_{\mathrm{s}}\right) \cdot \bar{F}_{\left((\mathrm{wq}-\mathrm{B})\left(1+\mathrm{r}_{\mathrm{s}}\right) / \mathrm{p}\right)-\left(1+\mathrm{r}_{\mathrm{f}}\right)}}{(\mathrm{wq}-\mathrm{B}) \cdot \bar{F}_{\left((\mathrm{wq}-\mathrm{B})\left(1+\mathrm{r}_{\mathrm{s}}\right) / \mathrm{p}\right)}}
\end{aligned}
$$


$\frac{\mathrm{dr}_{\mathrm{s}}}{\mathrm{dr}_{\mathrm{f}}}=-\frac{\partial \mathrm{U}}{\partial \mathrm{r}_{\mathrm{f}}} / \frac{\partial \mathrm{U}}{\partial \mathrm{r}_{\mathrm{s}}}=\frac{\mathrm{wq}-\mathrm{B}}{(\mathrm{wq}-\mathrm{B}) \cdot \bar{F}\left((\mathrm{wq}-\mathrm{B})\left(1+\mathrm{r}_{\mathrm{s}}\right) / \mathrm{p}\right)}=\frac{1}{\bar{F}\left((\mathrm{wq}-\mathrm{B})\left(1+\mathrm{r}_{\mathrm{s}}\right) / \mathrm{p}\right)}$.

From Eq.14, we can obtain,

$\mathrm{k}\left[\left(1+\mathrm{r}_{\mathrm{f}}\right)-\left(1+\mathrm{r}_{\mathrm{s}}\right) \bar{F}(\mathrm{k})\right]=\left(1+\mathrm{r}_{\mathrm{s}}\right) \int_{0}^{\mathrm{k}} \mathrm{D} \cdot \mathrm{f}(\mathrm{D}) \mathrm{dD}>0$,

so, $\left(1+\mathrm{r}_{\mathrm{f}}\right)-\left(1+\mathrm{r}_{\mathrm{s}}\right) \bar{F}(\mathrm{k})>0$

Therefore, we can obtain $\frac{d r_{s}}{d q}>0, \frac{d r_{s}}{d B}<0, \frac{d r_{s}}{d r_{f}}>0$.

Condition of $w q>B$ is discussed above. The retailer cannot achieve demand with his own fund and the supplier offers financing service to the retailer. The financing will occupy the fund of supplier and lead cost. So the interest rate of supplier financing $r_{s}$ will increase as the retailer's order quantity $\mathrm{q}$ and the risk-free rate $\mathrm{r}_{\mathrm{f}}$ increase and it will decrease as the retailer's own fund $\mathrm{B}$ increases.

The retailer's expected profit is

$$
\Pi_{r}^{3}\left(q, w, r_{s}\right)=p E[\min (D, q)]+A-(w q-B)\left(1+r_{s}\right)
$$

The optimal order quantity of the retailer is

$$
\mathrm{q}_{\mathrm{s}}^{3}\left(\mathrm{w}, \mathrm{r}_{\mathrm{s}}\right)=\bar{F}^{-1}\left(\mathrm{w}\left(1+\mathrm{r}_{\mathrm{s}}\right) / \mathrm{p}\right)
$$

The supplier's expected profit is

$$
\begin{aligned}
& \Pi_{s}^{3}\left(q, w, r_{s}\right)=B\left(1+r_{f}\right)+(w q-B)\left(1+r_{s}\right)-c q\left(1+r_{f}\right)=w q\left(1+r_{s}\right)-c q\left(1+r_{f}\right)- \\
& B\left(r_{s}-r_{f}\right)
\end{aligned}
$$

The supply chain efficiency is

$$
\begin{aligned}
& \Pi_{3}=\Pi_{r}^{3}+\Pi_{s}^{3}=p E[\min (D, q)]+A-(w q-B)\left(1+r_{s}\right)+w q\left(1+r_{s}\right)-c q\left(1+r_{f}\right)- \\
& B\left(r_{s}-r_{f}\right)=p E[\min (D, q)]+A+(B-c q)\left(1+r_{f}\right)
\end{aligned}
$$

A summary of the three conditions above can be given. At $t=0$, the retailer's own fund is B. The retailer orders products $\mathrm{q}$ from the supplier and pay a part of amount to the supplier $\alpha \mathrm{wq} \leq B$ in advance. $\alpha$ is the prepayment rate and $0 \leq \alpha \leq 1$. The remaining order valued $(1-\alpha) q$ will be financed from the supplier. The remaining fund $B-\alpha w q$ will be invested to earn the risk-free interest. The retailer will pay remaining loan wq $(1-\alpha)\left(1+r_{s}\right)$ to the supplier at the end of the sales season. When sales season ends, the retailer will gain sales revenue $p \cdot \min (D, q)$. If $p \cdot \min (D, q)+A+(B-\alpha w q)\left(1+r_{f}\right) \geq w q(1-\alpha)\left(1+r_{s}\right)$, the supplier will gain the remaining loan wq $(1-\alpha)\left(1+r_{s}\right)$. Otherwise, the retailer will be bankrupt, and the supplier can only get $\mathrm{p} \cdot \min (\mathrm{D}, \mathrm{q})+\mathrm{A}+(\mathrm{B}-\alpha \mathrm{wq})\left(1+\mathrm{r}_{\mathrm{f}}\right)$ back.

Then, the retailer's expected profit is

$$
\Pi_{r}\left(q, w, r_{s}\right)=p E[\min (D, q)]+A+(B-\alpha w q)\left(1+r_{f}\right)-w q(1-\alpha)\left(1+r_{s}\right)
$$

The optimal order quantity of the retailer is 


$$
\mathrm{q}_{\mathrm{s}}\left(\mathrm{w}, \mathrm{r}_{\mathrm{s}}\right)=\bar{F}^{-1}\left(\mathrm{w}\left(\left(1+\mathrm{r}_{\mathrm{s}}\right)+\alpha\left(\mathrm{r}_{\mathrm{f}}-\mathrm{r}_{\mathrm{s}}\right)\right) / \mathrm{p}\right)
$$

The supplier's expected profit is

$$
\Pi_{s}\left(q, w, r_{s}\right)=w q(1-\alpha)\left(1+r_{s}\right)+(\alpha w-c) q\left(1+r_{f}\right)
$$

The supply chain efficiency is

$$
\Pi=\Pi_{\mathrm{r}}+\Pi_{\mathrm{s}}=\mathrm{pE}[\min (\mathrm{D}, \mathrm{q})]+\mathrm{A}+(\mathrm{B}-\mathrm{cq})\left(1+\mathrm{r}_{\mathrm{f}}\right)
$$

Proposition 2. The supply chain efficiency is related to the risk-free rate $r_{f}$ and the retailer's own fund $\mathrm{B}$, but not related to the prepayment schemes that the retailer chooses. It can be proved according to Eq.22.

Mentioned as above, according to the prepayment rate $\alpha$, the retailer has three financing choices: Scheme 1(Full Payment, $\alpha=1)$; Scheme 2(Full Credit, $\alpha=0$ ); Scheme 3(Partly Payment, $0<\alpha<1)$.

When wq $\leq \mathrm{B}$, the retailer has two choices: Scheme 1 and Scheme 2. Assume that $\Delta \Pi_{\mathrm{r}}^{1,2}$ is the difference between two schemes of the retailer's expected profit, $\Delta \Pi_{\mathrm{s}}^{1,2}$ is the difference between of two schemes of the supplier's expected profit, we can obtain that,

$$
\begin{aligned}
& \Delta \Pi_{\mathrm{r}}^{1,2}=\Pi_{\mathrm{r}}^{1}-\Pi_{\mathrm{r}}^{2}=\mathrm{wq}\left(\mathrm{r}_{\mathrm{s}}-\mathrm{r}_{\mathrm{f}}\right) \\
& \Delta \Pi_{\mathrm{s}}^{1,2}=\Pi_{\mathrm{s}}^{1}-\Pi_{\mathrm{s}}^{2}=\mathrm{wq}\left(\mathrm{r}_{\mathrm{f}}-\mathrm{r}_{\mathrm{s}}\right)
\end{aligned}
$$

1. When $r_{s}<r_{f}, \Delta \Pi_{r}^{1,2}<0$, Scheme 2 is better than Scheme 1 for the retailer; $\Delta \Pi_{\mathrm{s}}^{1,2}>0$, it will be better for the supplier if retailer chooses Scheme 2 .

2. When $r_{s}=r_{f}, \Delta \Pi_{r}^{1,2}=\Delta \Pi_{s}^{1,2}=0$, two schemes will make the same effect on both supplier and retailer.

3. When $r_{s}>r_{f}, \Delta \Pi_{r}^{1,2}>0$, the retailer will prefer Scheme 1 to Scheme $2 ; \Delta \Pi_{\mathrm{s}}^{1,2}<0$, it will be better for the supplier if the retailer chooses Scheme 2.

When wq $>$ B, the retailer has two choices: Scheme 2 and Scheme 3. Assume that $\Delta \Pi_{\mathrm{r}}^{2,3}$ is the difference between two schemes of the retailer's expected profit, $\Delta \Pi_{\mathrm{s}}^{2,3}$ is the difference between of two schemes of the supplier's expected profit, we can obtain that,

$$
\begin{aligned}
& \Delta \Pi_{\mathrm{r}}^{2,3}=\Pi_{\mathrm{r}}^{2}-\Pi_{\mathrm{r}}^{3}=\mathrm{B}\left(\mathrm{r}_{\mathrm{f}}-\mathrm{r}_{\mathrm{s}}\right) \\
& \Delta \Pi_{\mathrm{s}}^{2,3}=\Pi_{\mathrm{s}}^{2}-\Pi_{\mathrm{s}}^{3}=\mathrm{B}\left(\mathrm{r}_{\mathrm{s}}-\mathrm{r}_{\mathrm{f}}\right)
\end{aligned}
$$

1.When $r_{s}<r_{f}, \Delta \Pi_{r}^{2,3}>0$, Scheme 2 is better than Scheme 3 for the retailer; $\Delta \Pi_{\mathrm{r}}^{2,3}<0$, it will be better for the supplier if the retailer chooses Scheme 3 .

2. When $r_{\mathrm{s}}=\mathrm{r}_{\mathrm{f}}, \Delta \Pi_{\mathrm{r}}^{2,3}=\Delta \Pi_{\mathrm{s}}^{2,3}=0$, two schemes will make the same effect on both supplier and retailer.

3. When $r_{s}>r_{f}, \Delta \Pi_{r}^{2,3}<0$, the retailer will prefer Scheme 3 to Scheme $2 ; \Delta \Pi_{r}^{2,3}>0$,it will be better for the supplier if the retailer chooses Scheme 2.

\section{Trade Credit Contract Parameters}

\section{The Optimal Interest Rate}

For $r_{s} \geq r_{f}$, Eq.9 implies that the supplier's expected profit decreases as $r_{s}$ increases. As a result, 
the optimal interest rate should be $r_{s}^{*}=r_{f}$. For the supplier, if $w$ approaches $c$, the upfront paid items are not profitable, and if $\mathrm{w}$ approaches $\mathrm{p} /\left(1+\mathrm{r}_{\mathrm{f}}\right)$, the retailer's small order quantity is suboptimal. Then, the optimal $\mathrm{w}$ is in the middle of $\left[\mathrm{c}, \mathrm{p} /\left(1+\mathrm{r}_{\mathrm{f}}\right)\right]$. We assume $\mathrm{W}=\mathrm{w}\left(1+\mathrm{r}_{\mathrm{s}}\right)$ is the wholesale price for delayed payment. If $r_{s}=p / c-1$, the only viable solution to the supplier is $\mathrm{w}=\mathrm{c}\left(\right.$ and $\left.\mathrm{W}=\mathrm{w}\left(1+\mathrm{r}_{\mathrm{s}}\right)=\mathrm{p}\right)$, which leaves supplier zero profit. Thus, a smaller $\mathrm{r}_{\mathrm{s}}$ can give supplier a larger room to adjust the wholesale price, and lead supplier to a larger profit. As a result, the supplier tends to decrease $r_{s}$ to $r_{s}^{*}=r_{f}$.

For the supplier and the retailer which is capital constrained, as $r_{s}$ decreases, the optimal discounted wholesale price and order quantity increase, i.e., the risk-neutral retailer is willing to bear more risk due to limited liability. On the other hand, the risk-neutral supplier continues to finance the retailer. In such a system it is efficient to encourage the retailer to take risks by lowering the borrowing rates, while the supplier compensates for the cheap trade credit by charging a larger wholesale price that would have resulted with the same retailer's order quantity.

When $r_{\mathrm{s}}^{*}=r_{\mathrm{f}}$, we can obtain the retailer's expected profit is

$$
\Pi_{\mathrm{r}}\left(\mathrm{q}, \mathrm{w}, \mathrm{r}_{\mathrm{s}}\right)=\mathrm{pE}[\min (\mathrm{D}, \mathrm{q})]+\mathrm{A}+(\mathrm{B}-\mathrm{wq})\left(1+\mathrm{r}_{\mathrm{f}}\right)
$$

And the optimal order quantity is

$$
\mathrm{q}_{\mathrm{s}}\left(\mathrm{w}, \mathrm{r}_{\mathrm{s}}\right)=\bar{F}^{-1}\left(\mathrm{w}\left(1+\mathrm{r}_{\mathrm{f}}\right) / \mathrm{p}\right)
$$

The supplier's expected profit is

$$
\Pi_{\mathrm{s}}\left(\mathrm{q}, \mathrm{w}, \mathrm{r}_{\mathrm{s}}\right)=(\mathrm{w}-\mathrm{c}) \mathrm{q}\left(1+\mathrm{r}_{\mathrm{f}}\right)
$$

The supply chain's total profit is

$$
\Pi=\Pi_{r}+\Pi_{s}=p E[\min (D, q)]+A+(B-c q)\left(1+r_{f}\right)
$$

From Equations above, we can obtain the retailer's expected profit and order quantity and the supplier's expected profit are not influenced by the prepayment rate $\alpha$, i.e., when $r_{s}=r_{f}$, the three payment schemes result the same to the retailer.

For $r_{s} \leq r_{f}$, the best decision for the retailer is full credit., i.e. the retailer pays the supplier up front nothing and invests all of its working capital to earn the risk-free interest. At the end-of-the-sales season, the retailer can obtain sales revenue $\operatorname{pmin}(D, q)$, capital investment, $\mathrm{B}\left(1+\mathrm{r}_{\mathrm{f}}\right)$, and collateral assets, A. Besides, the retailer has to repay its loan obligation $\mathrm{wq}\left(1+\mathrm{r}_{\mathrm{s}}\right)$.

Thus, the retailer's expected profit is

$$
\left.\Pi_{r}\left(q, w, r_{s}\right)=E[p \min (D, q)]+A+B\left(1+r_{f}\right)-w q\left(1+r_{s}\right)\right]^{+}
$$

And the supplier's expected profit is

$$
\Pi_{s}\left(q, w, r_{s}\right)=E\left[\min \left([\operatorname{pmin}(D, q)]+A+B\left(1+r_{f}\right), w q\left(1+r_{s}\right)\right)\right]-c q\left(1+r_{f}\right)
$$

As previously discussed, for $r_{s} \in\left[r_{f},+\infty\right), r_{s}^{*}=r_{f}$. For $r_{s} \in\left[0, r_{f}\right]$, we have the following result.

For $r_{s} \in\left[0, r_{f}\right]$, any pair $\left(w, r_{s}\right)$ satisfying $w\left(1+r_{s}\right)=w^{*}\left(1+r_{s}^{*}\right)$ is an optimal pair of contract parameters and gives the same expected profits to the supplier and retailer as $\left(\mathrm{w}^{*}, \mathrm{r}_{\mathrm{s}}^{*}\right)$.

\section{The Optimal Discounted Wholesale Price}

When the supplier's interest rate is fixed at $r_{s}^{*}=r_{f}$, the optimal order quantity for the retailer is 
$\mathrm{q}_{\mathrm{s}}\left(\mathrm{w}, \mathrm{r}_{\mathrm{s}}\right)=\bar{F}^{-1}\left(\mathrm{w}\left(1+\mathrm{r}_{\mathrm{f}}\right) / \mathrm{p}\right)$ and the supplier's expected profit is $\Pi_{\mathrm{s}}\left(\mathrm{q}, \mathrm{w}, \mathrm{r}_{\mathrm{s}}\right)=(\mathrm{w}-$ c) $q\left(1+r_{f}\right)$, no matter the retailer uses any of the three early payment schemes. The supply chain's total profit is always $\Pi=\mathrm{pE}[\min (\mathrm{D}, \mathrm{q})]+\mathrm{A}+(\mathrm{B}-\mathrm{cq})\left(1+\mathrm{r}_{\mathrm{f}}\right)$, which means the supply chain's profit is no influenced by the wholesale price. The trade credit contract is offered by the supplier. Thus, the optimal wholesale price is the solution to the supplier's expected profit maximization problem.

Let $\max \Pi_{\mathrm{s}}\left(\mathrm{q}, \mathrm{w}, \mathrm{r}_{\mathrm{s}}\right)=\max \left[(\mathrm{w}-\mathrm{c}) \mathrm{q}\left(1+\mathrm{r}_{\mathrm{f}}\right)\right]$, It can be derivate that

$$
\bar{F}^{-1}\left(\mathrm{w}\left(1+\mathrm{r}_{\mathrm{f}}\right) / \mathrm{p}\right)+(\mathrm{w}-\mathrm{c}) \cdot\left[\bar{F}^{-1}\left(\mathrm{w}\left(1+\mathrm{r}_{\mathrm{f}}\right) / \mathrm{p}\right)\right]^{\prime}=0
$$

We can get the optimal wholesale price $\mathrm{w}^{*}$ according to Eq.23.

\section{The Numerical Analysis}

In this section, we will analyze the numerical examples with the supply chain's operations. Parameters are set as follows: the production cost per unit is $\mathrm{c}=50$; the retail price per unit is $\mathrm{p}=150$; the wholesale price is $\mathrm{w}=100$; the retailer's own fund is $\mathrm{B}=20000$; the risk-free interest rate is $r_{f}=5 \%$. In addition, we assume that the stochastic demand $D$ obeys the uniform distribution of $[100,500]$.

When wq $\leq \mathrm{B}$, the retailer has two early payment choices:Scheme 1(Full Payment, $\alpha=1$ ) or Scheme 2(Full Credit, $\alpha=0$ ). When wq $>$ B, the retailer can choose Scheme 2(Full Credit, $\alpha=0$ ) or Scheme 3(Partly Payment, $0<\alpha<1$ ). The retailer has the same optimal order quantity in Scheme 2 and 3.Now we consider how $r_{s}$ changes influences the payment choice of retailer.

Let $r_{s}=2 \%\left(r_{s}<r_{f}\right)$. Fig. 1 shows that for the retailer, when $q \leq 200$, Scheme 2 is better than 1 ; when $\mathrm{q}>200$, Scheme 2 is better than 3. Fig.2 shows that for the supplier, when $\mathrm{q} \leq 200$, Scheme 1 is better than 2 ; when $q>200$, Scheme 3 is better than 2 . As a result, when $r_{s}<r_{f}$, optimal payment scheme for retailer is always full credit. While the supplier wishes the retailer to choose full payment or partly payment.

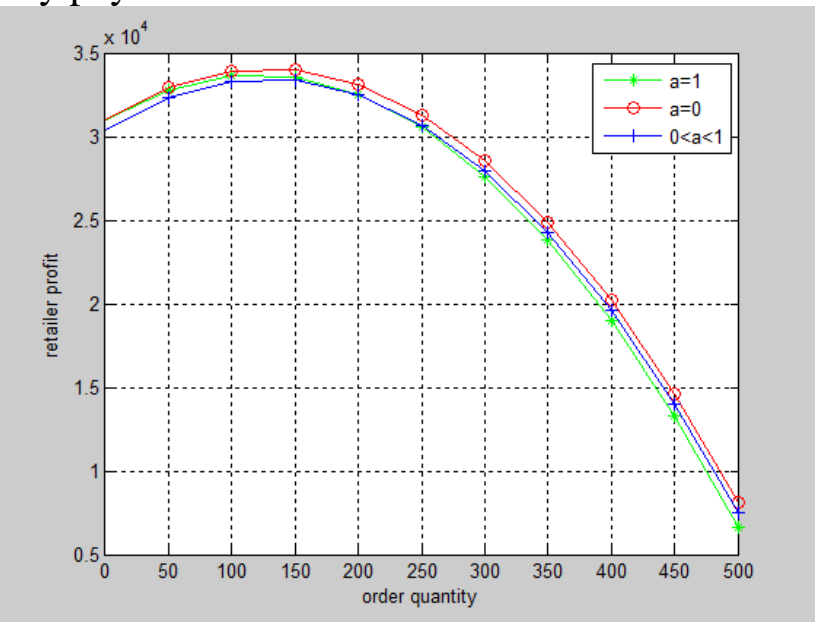

Fig. 1.the retailer's expected profit in the $r_{s}<r_{f}$ case 


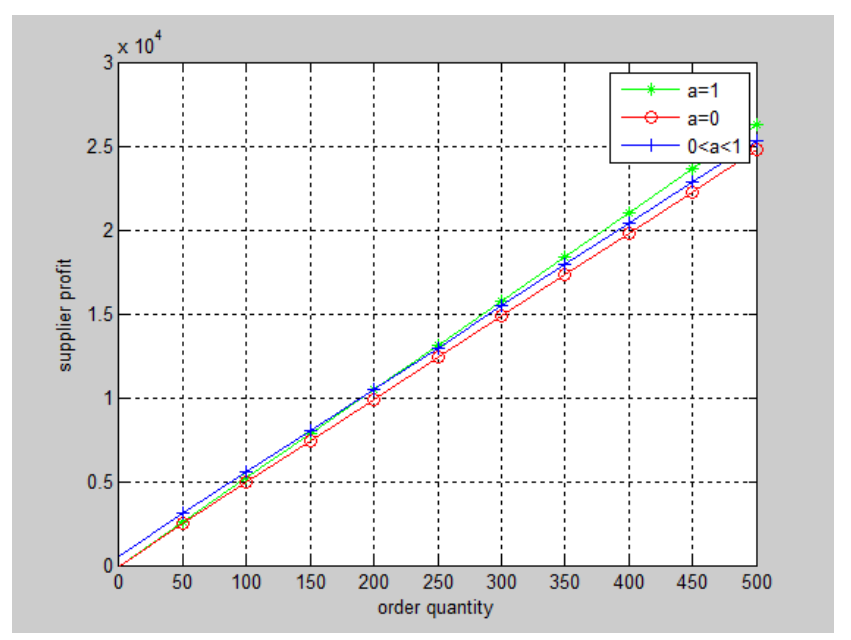

Fig.2.the supplier's expected profit in the $r_{s}<r_{f}$ case

Let $r_{s}=r_{f}=5 \%$. Fig. 3 and Fig. 4 show that for the retailer and supplier, when $r_{s}=r_{f}$, all the three payment schemes result the same. That is to say, the retailer can choose any one of them and his choice has no influence on his efficiency, as the same to the supplier.

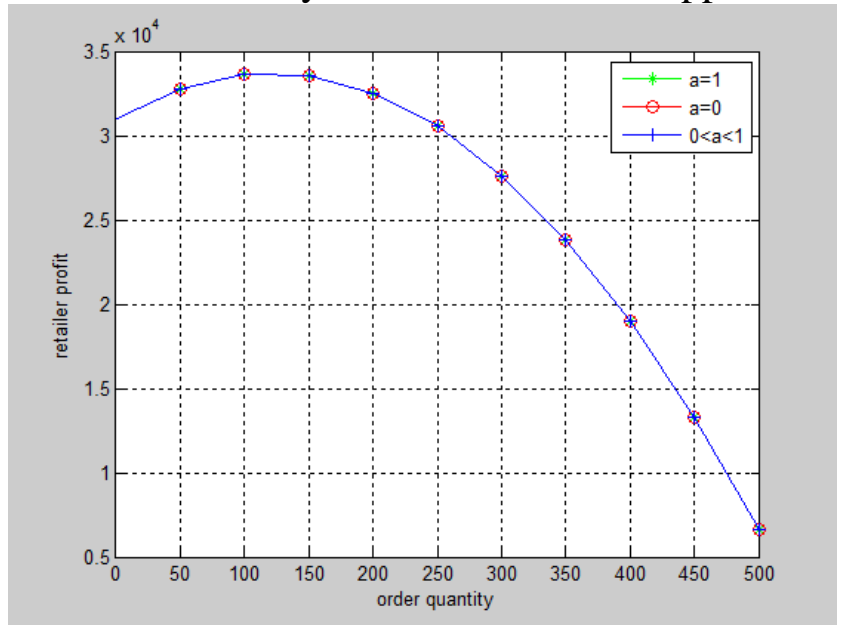

Fig.3.the retailer's expected profit in the $\mathrm{r}_{-} \mathrm{s}=\mathrm{r} \_\mathrm{f}$ case

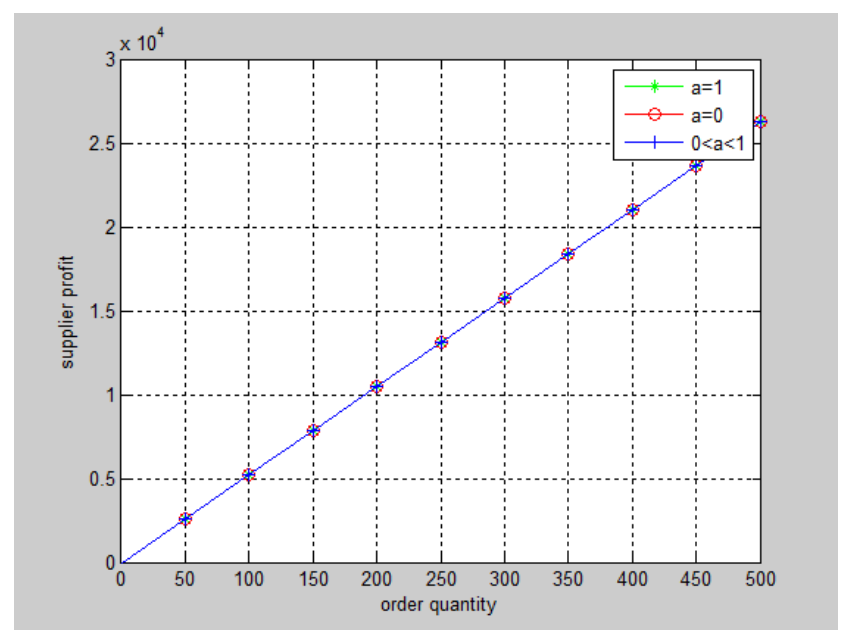

Fig.4.the supplier's expected profit in the $r_{s}=r_{f}$ case

Let $r_{s}=8 \%\left(r_{s}>r_{f}\right)$, Fig. 5 shows that for the retailer, when $q \leq 200$, Scheme 1 is better than 2; when $\mathrm{q}>200$, Scheme 3 is better than 2. Fig. 6 shows that for the supplier, when $\mathrm{q} \leq 200$, 
Scheme 2 is better than 1 ; when $q>200$, Scheme 2 is better than 3. As a result, when $r_{s}>r_{f}$, the retailer prefers to choose full payment or partly payment. While the supplier wishes the retailer to choose full credit.

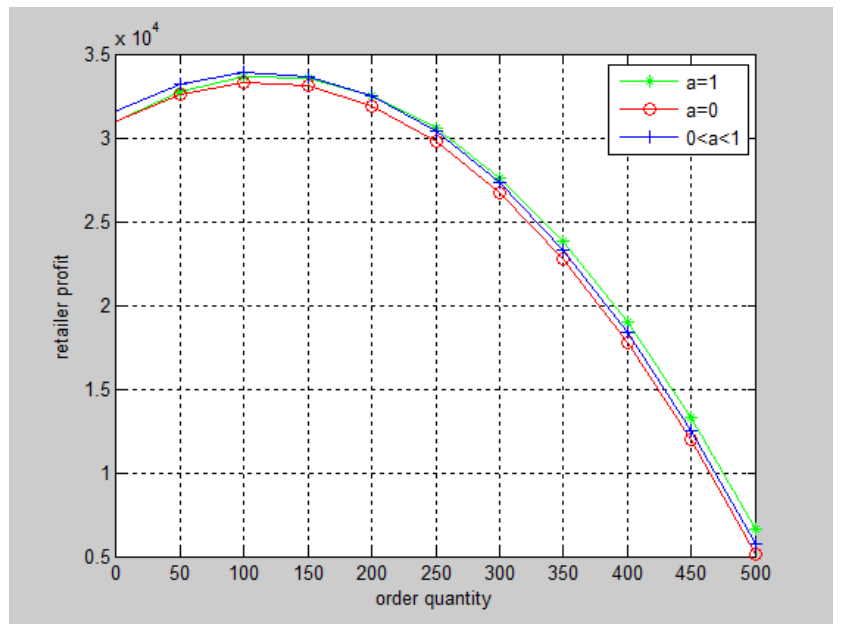

Fig.5.the retailer's expected profit in the $r_{-} s>r_{-} f$ case

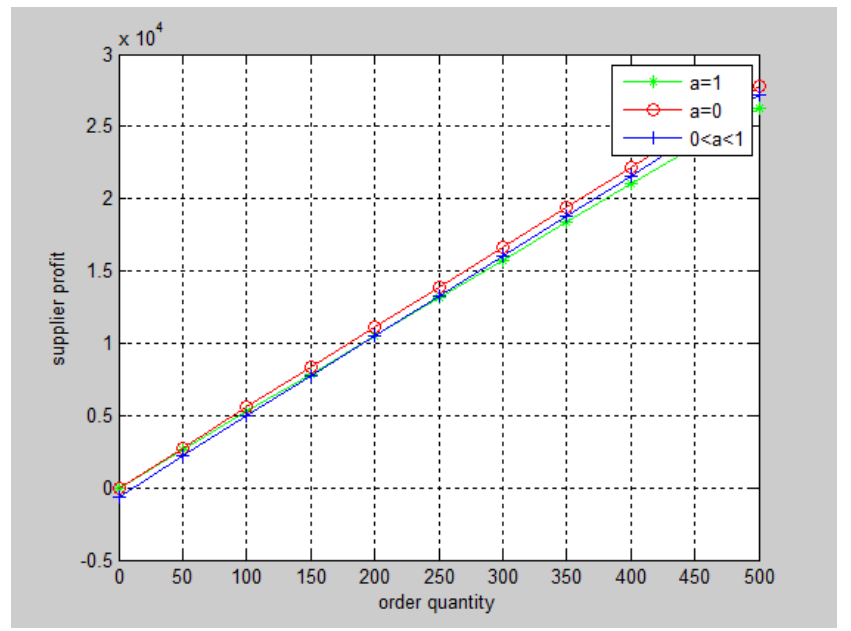

Fig.6.the supplier's expected profit in the $r_{-} s>r$ _f case

We can see from Section 3 that the supply chain's total profits are the same with three payment schemes. The numerical analysis results above show that, in a supply chain with a retailer and a supplier, the retailer and the supplier have conflict when they both pursue the maximization of their own profits. Thus, the supply chain coordination is needed. Supplier can offer retailer an optimal trade credit contract $\left(\mathrm{w}^{*}, \mathrm{r}_{\mathrm{s}}^{*}\right)$ to achieve a win-win. The retailer will always prefers to obtain the supplier early payment discounted financing if offered an optimal trade credit contract.

Proposition 2 implies that the supply chain's total profit is related to the retailer's own fund and risk-free rate, but not related to the prepayment rate. Respectively, Fig.7 and Fig. 8 show the supply chain's total profit with different retailer's own fund and different risk-free interest rate. As we can see, the supply chain's total profit increases as the retailer's own fund increases. It also increases as the risk-free interest rate increases, The supply chain efficiency improves with growing capital market competition. However, the capital market competition has influence on the supply chain efficiency slightly if the retailer's order quantity is large enough. 


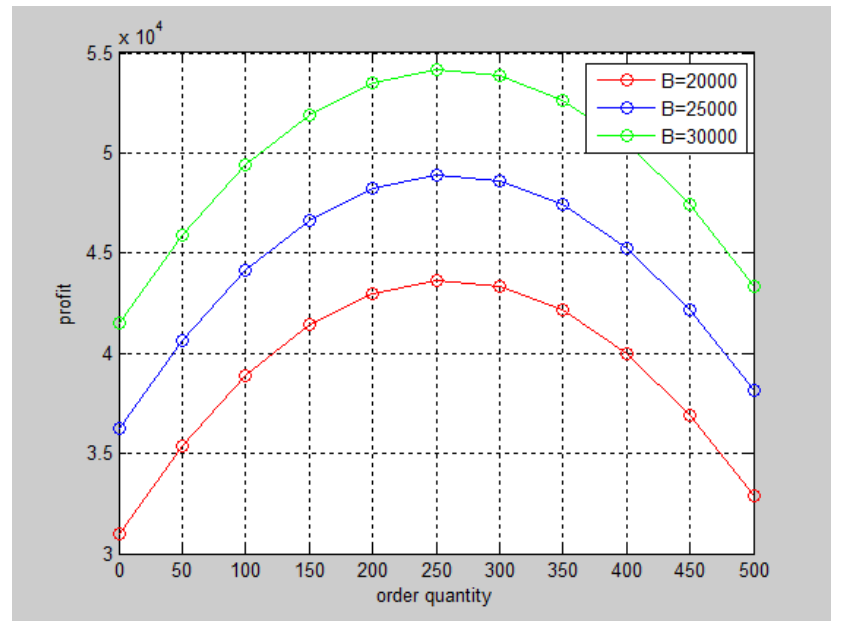

Fig.7.the supply chain's profit with different retailer's own fund

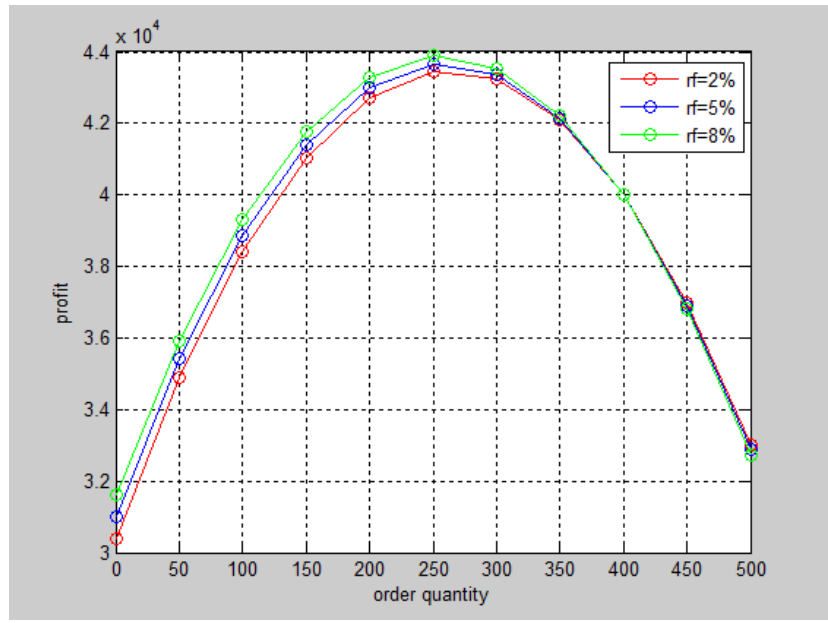

Fig. 8.the supply chain's profit with different risk-free interest rate

\section{Summary}

In this paper, we study the retailer's financing modes and the establishment of an optimal trade credit contract which is offered by the supplier. If the retailer has enough working capital, it can choose full repayment or full credit. Otherwise, it can pay nothing or partly according to the contract and its own fund. The retailer has three payment choices: Full Payment $(\alpha=1)$;Full Credit $(\alpha=0)$;Partly Payment $(0<\alpha<1)$. With numerical simulation,we draw the following conclusions:

- The change of supplier's interest rate $r_{s}$ has influence on the retailer's payment choices.

1.When $r_{s}<r_{f}$, the optimal payment scheme for retailer is always full credit. While the supplier wishes the retailer to choose full payment or partly payment.

2.When $r_{s}=r_{f}$, all the three payment schemes result the same for both the retailer and supplier.

3. When $r_{\mathrm{s}}>\mathrm{r}_{\mathrm{f}}$, the retailer prefers to choose full payment or partly payment. While the supplier wishes the retailer to choose full credit.

- In a supply chain with a retailer and a supplier, the retailer and the supplier have conflict when they both pursue the maximization of their own profits. Thus, the supply chain coordination is needed. Supplier can offer retailer an optimal trade credit contract to achieve a win-win. The retailer will always prefers to obtain the supplier early payment discount financing if offered an optimal trade credit contract.

- The supply chain's total profits are the same in three payment schemes. The profit is related to the retailer's own fund and risk-free interest rate. It increases as the retailer's own fund increases. 
Besides, the supply chain efficiency improves with growing capital market competition. However, the capital market competition has influence on the supply chain efficiency slightly if the retailer's order quantity is large enough.

In this paper, we only consider the supply chain consists of a single retailer and a single supplier. In the following research, we will study the financing problem under the complex supply chain system with commercial banks or more enterprises.

\section{Acknowledgement}

This research was financially supported by the National Natural Science Foundation of China (China's supply chain management innovation mode and method of research, Grant No.: 71131003).College of Humanities and Social Science Research Project of Guangdong Province (supply chain funds flow of financial synergy and performance management research. Grant No.: 11WYXM005).

\section{References}

[1] Buzacott J A,Zhang R Q,2004. Inventory management with asset-based financing. Management Science 24,1274-1292.

[2] N.R.Srinivasa Raghavan, Vinit Kumar Mishra,2011. Short-term financing in a cash-constrained supply chain. International Journal of Production Economics 134, 407-412.

[3] Margarita Protopappa-Sieke, Ralf W. Seifert,2010. Interrelating operational and financial performance measurements in inventory control. European Journal of Operational Research 204, 439-448.

[4] Lee C.H., Rhee B.D. Coordination contracts in the presence of positive inventory financing costs [J]. International Journal of Production Economics, 2010, 124(2): 331-339.

[5] Panos Kouveils, Wenhui Zhao.2012.Financing the Newsvendor:Supplier vs Bank,and the Structure of Optimal Trade Credit Contracts.Operations Research 60(3),566-580.

[6] Zhou Yongwu, Zhong Yuanguang, Wahab M.I.M. ,2011. Retailer's optimal ordering policy and payment plan under two-part trade credit. European Journal of Operational Research.

[7] Yuan-Guang Zhong,Yong-Wu Zhou,2012.The model and algorithm for determining optimal ordering/trade-credit policy of supply chains. Applied Mathematics and Computation 219,3809-3825.

[8] Chang Hwan Lee, Byong-Duk Rhee,2011. Trade credit for supply chain coordination. European Journal of Operational Research 214, 136-146.

[9] Zhong Y.G., Zhou Y.W., Li B.X., Wang S.D. The retailer's optimal ordering and pricing policies with supply chain financing [J]. Journal of Management Sciences in China, 2011, 6(14):57-67.

[10] Yan Nina, Sun Baowen. Optimal strategies for supply chain financing system based on warehouse receipts financing with credit line $[\mathrm{J}]$. Systems Engineering-Theory \&Practice, 2011,9(31):1674-1679.

[11]Li Yixue, Feng Gengzhong., Xu Y.u Research On Loan-to-value Ratio of Inventory Financing under Randomly-fluctuant Price [J]. Systems Engineering-Theory \& Practice, 2007, 12(12): 42-48.

[12]Chen Xiangfeng, Zhu Daoli, Ying Wenjun. Financial and operation decisions in budget-constrained supply chain[J]. Journal of Management Sciences in China, 2008, 6(11):70-77.

[13]Zhang Yuanyuan, Li Jianbin. Optimal inventory management under inventory 
financing[J].Systems Engineering-Theory \& Practice, 2008, 9 (28): 29-38.

[14] Yang Wang, Yunlu Ma, Yuhe Zhan. Study on Supplier-Led Supply Chain Finance, Research Journal of Applied Sciences, Engineering and Technology. 2012, 4(18): 3375-3380.

[15] Hu Benyong, Peng Qiyuan, Wang Xingyu. Supply chain option flexibility contract with consideration of influence of shortage of capital [J]. Journal of Management Sciences in China, 2009, 12(6):62-71.

[16] Liu Tao, Li Bangyi, Gong Yande. Supply chain coordination policy and measure under trade credit [J]. Systems Engineering-Theory \& Practice, 2010, 30(8): 1345-1354.

[17]Zhang Qinhong, Luo Jianwen. Coordination of supply chain with trade credit under bilateral information asymmetry [J]. Systems Engineering-Theory \& Practice, 2009, 29(9): 32-40.

[18] Cao Zonghong, Zhou Yongwu. Supply chain coordination model with demand influenced by shortage for deteriorating items [J]. Journal of Systems Engineering, 2011, 26(1): 50-59. 